\title{
Changes of Langerhans cells during skin ageing
}

\author{
Barbara Zegarska, ${ }^{1,2}$, Katarzyna Pietkun', Paulina Giemza-Kucharska², Tomasz Zegarski ${ }^{3}$, Maciej S. Nowacki ${ }^{4}$, \\ Krystyna Romańska-Gocka ${ }^{1}$
}

\author{
${ }^{1}$ Chair of Cosmetology and Aesthetic Dermatology, Ludwik Rydygier's Collegium Medicum in Bydgoszcz, Nicolaus Copernicus \\ University in Torun, Poland \\ ${ }^{2}$ Clinica Dermatoestetica, Bydgoszcz, Poland \\ ${ }^{3}$ Centre for Physical Education and Sport, Ludwik Rydygier's Collegium Medicum in Bydgoszcz, Nicolaus Copernicus University \\ in Torun, Poland \\ ${ }^{4}$ Chair and Department of Surgical Oncology, Ludwik Rydygier's Collegium Medicum in Bydgoszcz, Nicolaus Copernicus University \\ in Torun, Oncology Centre-Professor Franciszek Łukaszczyk Memorial Hospital in Bydgoszcz, Poland
}

Adv Dermatol Allergol 2017; XXXIV (3): 260-267

DOI: https://doi.org/10.5114/ada.2017.67849

\begin{abstract}
Introduction: During the process of skin ageing, changes occur in all skin layers and all cells, including the Langerhans cells.

Aim: To assess whether any quantitative difference in the number of CD1a+ LC cells $/ \mathrm{mm}^{2}$ and HLA-DR $\mathrm{LC}^{+}$cells/ $\mathrm{mm}^{2}$ as well as in their morphological features can be observed during the course of different types of skin ageing. Material and methods: The study was conducted in a group of 60 women, which was divided into three independent groups: group I with symptoms of menopausal skin ageing, group II with symptoms of photoageing, group III with symptoms of chronological ageing. Skin biopsy samples were taken from the pre-auricular region from all of the participants. The number of $\mathrm{CD} 1 \mathrm{a}^{+} \mathrm{LC}$ cells $/ \mathrm{mm}^{2}$ and $\mathrm{HLA}-\mathrm{DR}^{+} \mathrm{LC}$ cells $/ \mathrm{mm}^{2}$ as well as their morphological features were evaluated.

Results: The frequency of CD1a+ LC and HLA-DR+ LC in all the studied groups was diverse. In groups I and III, the LC with large cell bodies and long, multi-branched processes were the majority. In group II, the LC had small cell bodies and their processes were mainly short and unbranched.

Conclusions: The obtained results indicate the presence of quantitative and morphological changes of the CD1a ${ }^{+}$ $\mathrm{LC}$ and $\mathrm{HLA}-\mathrm{DR} \mathrm{R}^{+} \mathrm{LC}$ during the course of different types of skin ageing.
\end{abstract}

Key words: skin ageing, Langerhans cells, cells distribution.

\section{Introduction}

Skin ageing is a complex process depending on external, genetic and hormonal factors [1-5]. Increased susceptibility to skin infections and rising incidence of skin neoplasms observed in the elderly indicate that skin immunity decreases with age [6-9].

Langerhans cells (LC) constitute approximately 3-8\% of all the cells in the epidermis. They play a role in the pathogenesis of various dermatoses and take part in skin neoplastic transformation. The number and appearance of LC change depending on the type of dermatosis and also during the skin ageing processes [10-13]. The main roles attributed to $L C$ in the skin immune system concern the immune surveillance. They are the most abundant in the basal layer and the spinous layer of the epidermis.
Under physiological conditions the number of LC in the epidermis ranges from 450 to 1000 per $\mathrm{mm}^{2}[8,10,11$, 14]. The expression of CD1a molecules on the LC surface is a characteristic feature of this cell line. Monoclonal Anti-Human HLA-DR antibodies and Anti-Human CD1a antibodies can be considered a good marker of Langerhans cells $[15,16]$.

\section{Aim}

1) Quantitative evaluation of $\mathrm{LC} / \mathrm{mm}^{2}-\mathrm{CD} 1 \mathrm{a}^{+}, \mathrm{HLA}-\mathrm{DR} \mathrm{R}^{+}$in different types of skin ageing.

2) The assessment whether there is any difference in the appearance of $\mathrm{LC}$ depending on the type of skin ageing can be observed.

Address for correspondence: Barbara Zegarska MD, PhD, Chair of Cosmetology and Aesthetic Dermatology, Ludwik Rydygier's Collegium Medicum, Nicolaus Copernicus University, 13-15 Jagiellońska St, 85-096 Bydgoszcz, Poland, phone: +48 601936608 , e-mail: baskazegarska@op.pl

Received: 29.06.2016, accepted: 19.10.2016. 


\section{Material and methods}

The study included the group of 60 healthy women with various symptoms of skin ageing at the age from 26 to 62 years. Then, three independent groups were distinguished, every group contained 20 persons.

Group I consisted of women (with symptoms of menopausal skin ageing) at the age from 45 to 62 years, mean age $52.70 \pm 4.73$, non-smoking, not menstruating, not using hormonal replacement therapy, not using solarium and sunbathes and using photoprotection.

Group II (photoageing) comprised 20 women at the age from 26 to 49 years, mean age was $38.3 \pm 7.46$. Eleven (55\%) women in this group smoked cigarettes from several to several dozen cigarettes a day. This group included menstruating women, who do not use hormonal replacement therapy and hormonal contraception. Analysed women often used sunbathes, attended solarium from 2-12 times a month and they did not use photoprotection.

The third group was formed by women (with symptoms of chronological skin ageing) between 49 and 62 years of age - mean age was $55 \pm 3.78$. All women in this group did not smoke, used hormonal replacement therapy during the study, did not attend solarium, did not tan and used photoprotection daily.

Skin biopsy samples were taken from the pre-auricular region using biopsy punch, under topical anaesthesia with $2 \%$ lignocaine solution, and then fixed in $10 \%$ buffered formalin. In order to detect cellular antigens in the epidermis with the use of the immunofluorescence (IMF) method, antibodies marked with fluorochromes of different fluorescent colours were used.

Immunofluorescence examinations were performed using: indirect immunofluorescence (IIF) method and double immunohistochemistry (ID).

The types of primary antibodies used in the experiments are shown in Table 1, and types of secondary antibodies are shown in Table 2 .

The analysed material was incubated with the following antibodies:
- mouse anti-human CDla (dilution 1 : 50) + anti-mouse (donkey) IgG/TRITC (dilution $1: 50$ ),

- mouse anti-human HLA-DR (dilution 1 : 50) + antimouse (goat) IgG/FITC (dilution $1: 50$ ).

\section{Cell counting}

In FITC-and TRITC-marked preparations the cells were observed under the fluorescence microscope at the magnification of $40 \times$. All the cells observed in the high power field were counted and multiplied by 16 in order to obtain the number of cells per $\mathrm{mm}^{2}$ of epidermis $\left(\mathrm{LC} / \mathrm{mm}^{2}\right)$.

A four-point scale was used, the points being as follows: 0 - complete lack of cells, 1 - from $1 \%$ to $50 \%$ of cells, 2 - from $51 \%$ to $99 \%$ of cells, $3-100 \%$ of cells.

\section{Morphological characteristics}

Morphological characteristics of LC was based on the assessment of: the size of the cell body (small and/or large), the dendritic processes (short unbranched and/ or long branched).

The distribution of LC in the epidermis (regular or irregular) and in the dermis (lack of, single or infiltrations) was also assessed.

\section{Results}

\section{The assessment of CD1a+ LC in the studied} groups

The frequency of CD1a+ $L C$ varied in all the groups. The highest number of CD1a+ $\mathrm{LC}$ was observed in group III$\min =128, \max =736(x=316.8 \pm 190.8, m e=240)$ and a slightly lower number was in group $\|-\min =80, \max =$ $720(x=303.4 \pm 158.6, m e=296)$. In group I the number of CD1a ${ }^{+}$LC was the lowest $-\min =80, \max =368 / \mathrm{mm}^{2}(x=$ $200.8 \pm 68.2$, $m e=192$ ). A statistical analysis of the groups was performed using the Mann-Whitney test and revealed statistically significant differences between groups I and III $(p=0.013)$. When the number of CD1a LC was compared between groups I and II, the differences were also observed, but they were not statistically significant $p>0.05$ (Figure 1).

Table 1. Primary antibodies used in the experiments

\begin{tabular}{lccc}
\hline Identification of antibodies & Type of antibodies & Specificity of antibodies & Immunogenicity \\
\hline MCA80GA (Serotec) & Mouse IgG2a (monoclonal) & Anti-human CD1a & $\begin{array}{l}\text { Human thymocytes, } \\
\text { spleen lymphocytes }\end{array}$ \\
\hline Anti-HLA-DR (Serotec) & Mouse IgG1 (monoclonal) & Anti-human HLA-DR & Human lymphoma cells \\
\hline
\end{tabular}

Table 2. Secondary antibodies used in the experiments

\begin{tabular}{lccc}
\hline Identification of antibodies & Type of antibodies & Specificity of antibodies & Fluorochrome \\
\hline $\begin{array}{l}\text { Jackson Immuno Research } \\
\text { Laboratories, INC (USA) }\end{array}$ & Donkey anti-lgG (conjugate) & Against mouse IgG & TRITC \\
\hline $\begin{array}{l}\text { Jackson Immuno Research } \\
\text { Laboratories, INC (USA) }\end{array}$ & Goat anti-IgG (conjugate) & Against mouse IgG & FITC \\
\hline
\end{tabular}




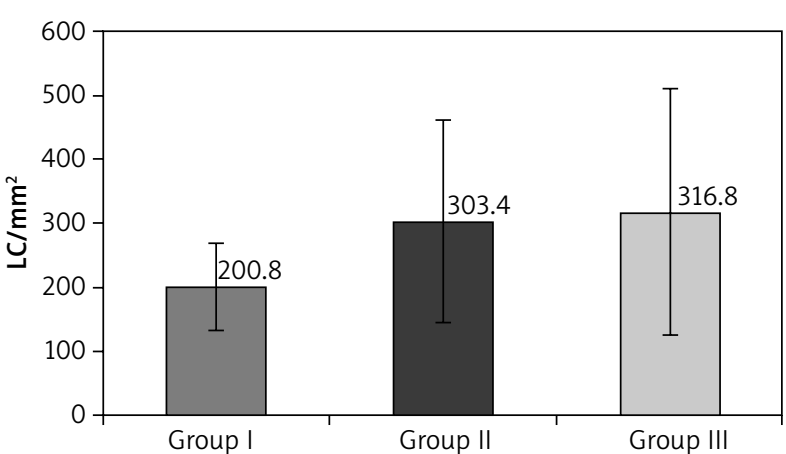

Figure 1. Mean CD1a + LC values in individual groups

\section{Quantitative assessment of HLA-DR+ LC in the studied groups}

When comparing the minimum, maximum and mean values of HLA-DR+ LC, differences between the studied groups were found, but they were not statistically significant $(p>0.05)$. In group I, HLA-DR ${ }^{+} L C$ amounted to: $\min =64, \max =656(x=270.4 \pm 171.3)$, $m e=208$; in group II $-\min =32, \max =688(x=234 \pm 157.6$, e $=208)$; and in group III: HLA-DR+ LC $\min =64, \max =656(x=270.4$ \pm 171.3 , $m e=208)$ (Figure 2).

\section{Analysis of the correlation between CD1a+ and HLA-DR+}

The significance of the correlation for $\mathrm{CD} \mathrm{a}^{+}$and HLA$\mathrm{DR}^{+}$was assessed with the use of Spearman's correlation coefficient. A statistically significant correlation was found in all three groups for CD1a+ and HLA-DR+. In group I $-r=0.8978, p=0.0001$, in group $\|-r=0.9748, p=$ 0.0001 and in group $\| I-r=0.9837, p=0.0001$.

\section{Morphological characteristics of LC in the studied groups}

In group I Langerhans cells were mainly characterised by a large cell body (in $85 \%$ of the participants) and long, branched dendritic processes (in 65\% of the participants). The distribution of LC in the epidermis was regular in 15 (i.e. 75\%) women. Infiltrations of LC in the dermis were observed in 3 participants. Single cells were observed in $9(45 \%)$ women, 5 of which were single HLA$\mathrm{DR}^{+} \mathrm{LC}$ cells (Table 3, Figure 3).

In group II, LC differed in the size of the cell body, shape of dendritic processes and distribution (Table 3). In the majority of participants - 12 (60\%) women, cell bodies were small. In this group, LC generally had short dendritic processes (55\%). The distribution of $L C$ in the epidermis was regular in 10 women and irregular in 10 women. In the dermis, LC appeared as infiltrations in 8 participants, single cells were observed in 6 participants and in 6 participants these cells were not observed (Table 3, Figures $4 \mathrm{~A}$ and $\mathrm{B}$ ).

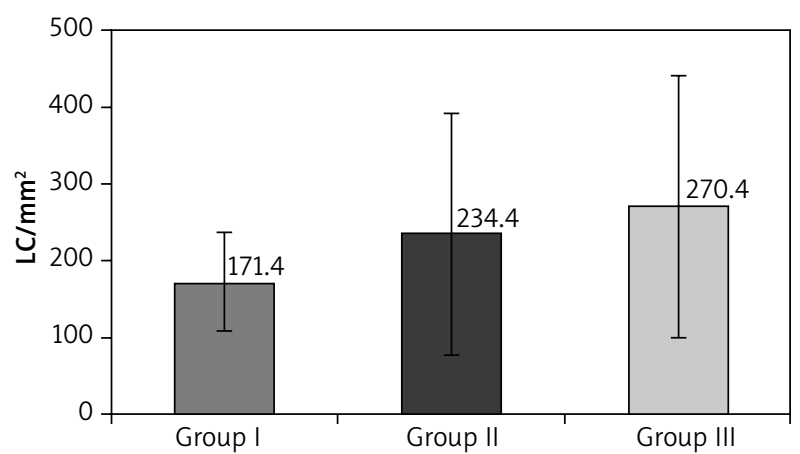

Figure 2. Mean HLA-DR+ LC values in individual groups

In group III (Table 3), in 16 (80\%) participants LC were characterised by large cell bodies and numerous, long, branched processes. In 4 (i.e. 20\%) participants LC of a completely different morphological structure were observed: with small cell bodies and short, unbranched processes (Figures $5 \mathrm{~A}$ and $\mathrm{B}$ ). The distribution of LC cells in the epidermis was irregular. The presence of $L C$ in the dermis was not detected.

When comparing the size of cell bodies of LC in the studied groups it was observed that the difference between LC in group I and in group III was not statistically significant. In group II, the cell bodies of LC were small and statistically significantly different compared to the LC from group I ( $p=0.0033)$ and different from the LC from group III ( $p=0.025)$ (Table 3, Figure 6).

When comparing the appearance of dendritic processes of LC in the studied groups, a statistically significant difference between them was not found (Figure 7), but the difference between group II and group III was nearly statistically significant $(p=0.052)$.

When comparing the distribution of LC in epidermis (Figure 8) and in the dermis, no statistically significant difference was found (Figure 9). A statistically significant difference was noted between groups I and III ( $p=0.001)$ and between group II and group III $(p=0.001)$.

\section{Discussion}

The increasing incidence of neoplasms as well as bacterial, fungal and viral infections in elderly people indicates the disturbances in the skin immune system. Immune ageing is a multifactor process in the skin. There is some evidence that different immune response cells change during the skin ageing process [7, 17-21]. The changes concerning LC during the process of skin ageing occur in all the types of this process. Authors most frequently describe them as a decrease in the general number of LC or as changes in their appearance. Such changes are quite frequently accompanied by disturbances of the presentation to T lymphocytes [22-25]. 
Table 3. Morphological characteristics of LC: group I, II, III

\begin{tabular}{|c|c|c|c|c|c|c|c|c|c|c|c|c|c|c|c|c|c|c|}
\hline \multirow{4}{*}{$\begin{array}{l}\bar{\Phi} \\
\stackrel{\bar{g}}{\xi} \\
\frac{3}{z}\end{array}$} & \multicolumn{6}{|c|}{ Cell body } & \multicolumn{6}{|c|}{ Dendritic processes } & \multirow{2}{*}{\multicolumn{3}{|c|}{$\begin{array}{l}\text { Distribution - } \\
\text { epidermis }\end{array}$}} & \multirow{2}{*}{\multicolumn{3}{|c|}{$\begin{array}{l}\text { Distribution - } \\
\text { dermis }\end{array}$}} \\
\hline & \multirow{2}{*}{\multicolumn{3}{|c|}{$\begin{array}{l}\text { Small } \\
\text { Group }\end{array}$}} & \multirow{2}{*}{\multicolumn{3}{|c|}{$\begin{array}{l}\text { Large } \\
\text { Group }\end{array}$}} & \multirow{2}{*}{\multicolumn{3}{|c|}{$\begin{array}{c}\text { Short unbranched } \\
\text { Group }\end{array}$}} & \multirow{2}{*}{\multicolumn{3}{|c|}{$\begin{array}{c}\text { Long branched } \\
\text { Group }\end{array}$}} & & & & & & \\
\hline & & & & & & & & & & & & & \multicolumn{3}{|c|}{ Group } & \multicolumn{3}{|c|}{ Group } \\
\hline & 1 & II & III & I & II & III & $\mathrm{I}$ & II & III & I & II & III & I & II & III & I & II & III \\
\hline 1 & 0 & 1 & 2 & 3 & 2 & 1 & 2 & 3 & 2 & 1 & 0 & 1 & r & ir & ir & - & - & - \\
\hline 2 & 0 & 1 & 1 & 3 & 2 & 2 & 2 & 1 & 1 & 1 & 2 & 2 & r & ir & r & s & $\mathrm{i}$ & - \\
\hline 3 & 2 & 2 & 1 & 1 & 1 & 2 & 2 & 2 & 1 & 1 & 1 & 1 & $r$ & $r$ & r & - & $\mathrm{i}$ & - \\
\hline 4 & 3 & 2 & 1 & 0 & 1 & 2 & 3 & 2 & 1 & 0 & 1 & 2 & r & r & r & s & $\mathrm{i}$ & - \\
\hline 5 & 1 & 3 & 1 & 2 & 0 & 2 & 1 & 2 & 1 & 2 & 1 & 2 & ir & ir & $r$ & $\mathrm{~s}$ & s & - \\
\hline 6 & 1 & 3 & 1 & 2 & 0 & 2 & 1 & 2 & 1 & 2 & 1 & 2 & ir & $r$ & $r$ & i & - & - \\
\hline 7 & 1 & 3 & 1 & 2 & 0 & 2 & 1 & 3 & 1 & 2 & 0 & 2 & $r$ & ir & $r$ & i & - & - \\
\hline 8 & 1 & 3 & 2 & 2 & 0 & 1 & 1 & 0 & 2 & 2 & 3 & 1 & $r$ & $r$ & $r$ & - & s & - \\
\hline 9 & 1 & 2 & 1 & 2 & 1 & 2 & 1 & 2 & 1 & 2 & 1 & 2 & $r$ & $r$ & $r$ & - & $\mathrm{i}$ & - \\
\hline 10 & 1 & 2 & 1 & 2 & 1 & 2 & 2 & 2 & 1 & 1 & 1 & 2 & $r$ & ir & ir & - & $\mathrm{s}$ & - \\
\hline 11 & 1 & 2 & 1 & 2 & 1 & 2 & 2 & 2 & 1 & 1 & 1 & 2 & $r$ & ir & ir & $\mathrm{s}$ & i & - \\
\hline 12 & 1 & 1 & 1 & 2 & 2 & 2 & 1 & 1 & 2 & 2 & 2 & 1 & $r$ & $r$ & $\mathrm{r}$ & ir & $\mathrm{s}$ & - \\
\hline 13 & 1 & 1 & 2 & 2 & 2 & 1 & 1 & 1 & 2 & 2 & 2 & 1 & $r$ & ir & ir & $\mathrm{s}$ & i & - \\
\hline 14 & 1 & 1 & 1 & 2 & 2 & 2 & 1 & 1 & 1 & 2 & 2 & 2 & ir & ir & ir & - & i & - \\
\hline 15 & 2 & 2 & 1 & 1 & 1 & 2 & 2 & 2 & 1 & 1 & 1 & 2 & $r$ & ir & $r$ & $\mathrm{~s}$ & $\mathrm{~s}$ & - \\
\hline 16 & 1 & 1 & 1 & 2 & 2 & 2 & 1 & 1 & 1 & 2 & 2 & 2 & $r$ & $r$ & ir & $\mathrm{s}$ & - & - \\
\hline 17 & 1 & 2 & 1 & 2 & 1 & 2 & 1 & 2 & 1 & 2 & 1 & 2 & ir & $r$ & $r$ & - & i & - \\
\hline 18 & 1 & 1 & 2 & 2 & 2 & 1 & 1 & 1 & 2 & 2 & 2 & 1 & $r$ & $r$ & ir & $\mathrm{s}$ & $\mathrm{s}$ & - \\
\hline 19 & 1 & 1 & 1 & 2 & 2 & 2 & 1 & 1 & 1 & 2 & 2 & 2 & ir & $r$ & ir & - & - & - \\
\hline 20 & 1 & 2 & 1 & 2 & 1 & 2 & 1 & 1 & 1 & 2 & 2 & 2 & $r$ & $r$ & ir & $\mathrm{s}$ & - & - \\
\hline
\end{tabular}

$r$-regular, ir-irregular, s-single, $i$-infiltration.
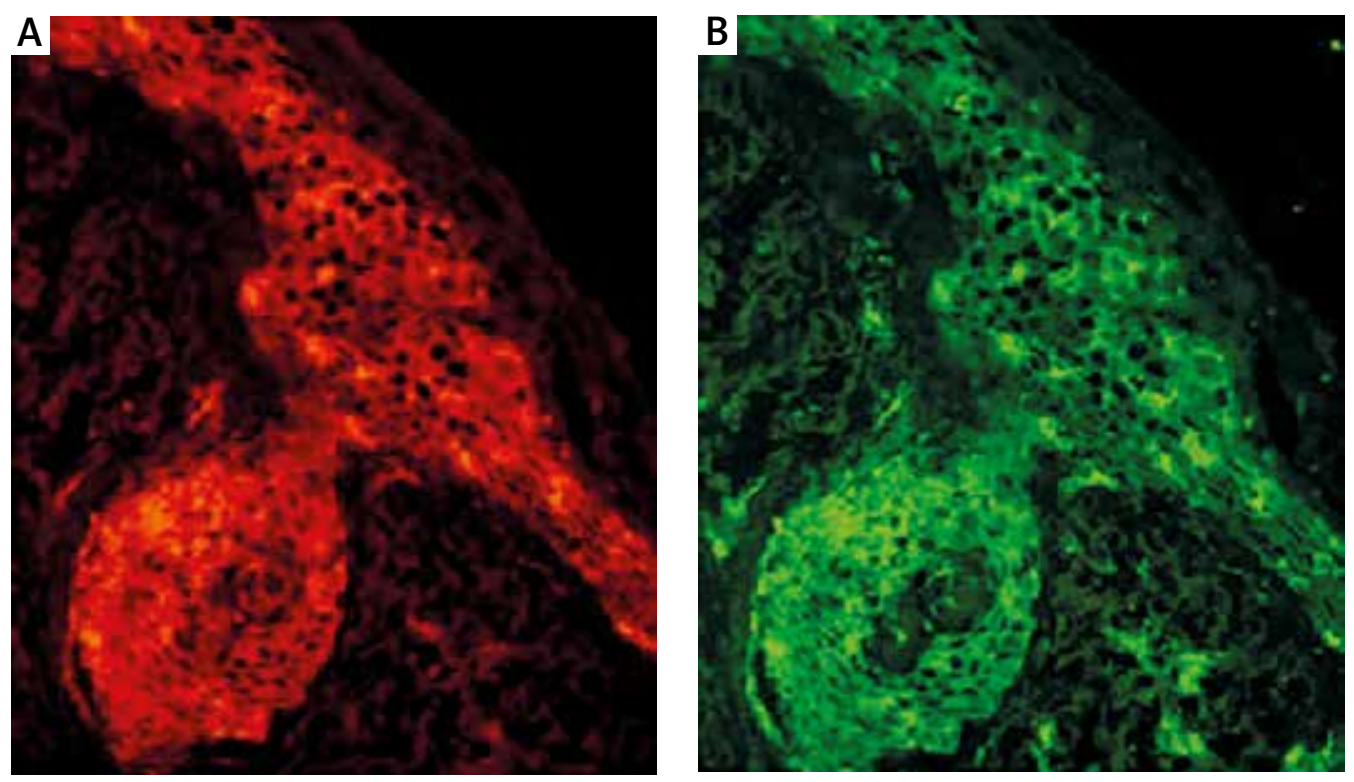

Figure 3. Langerhans cells: A - CD1a+ LC (TRITC), B - HLA-DR+ LC (FITC). Visible LC with large cell bodies and long, branched dendritic processes 

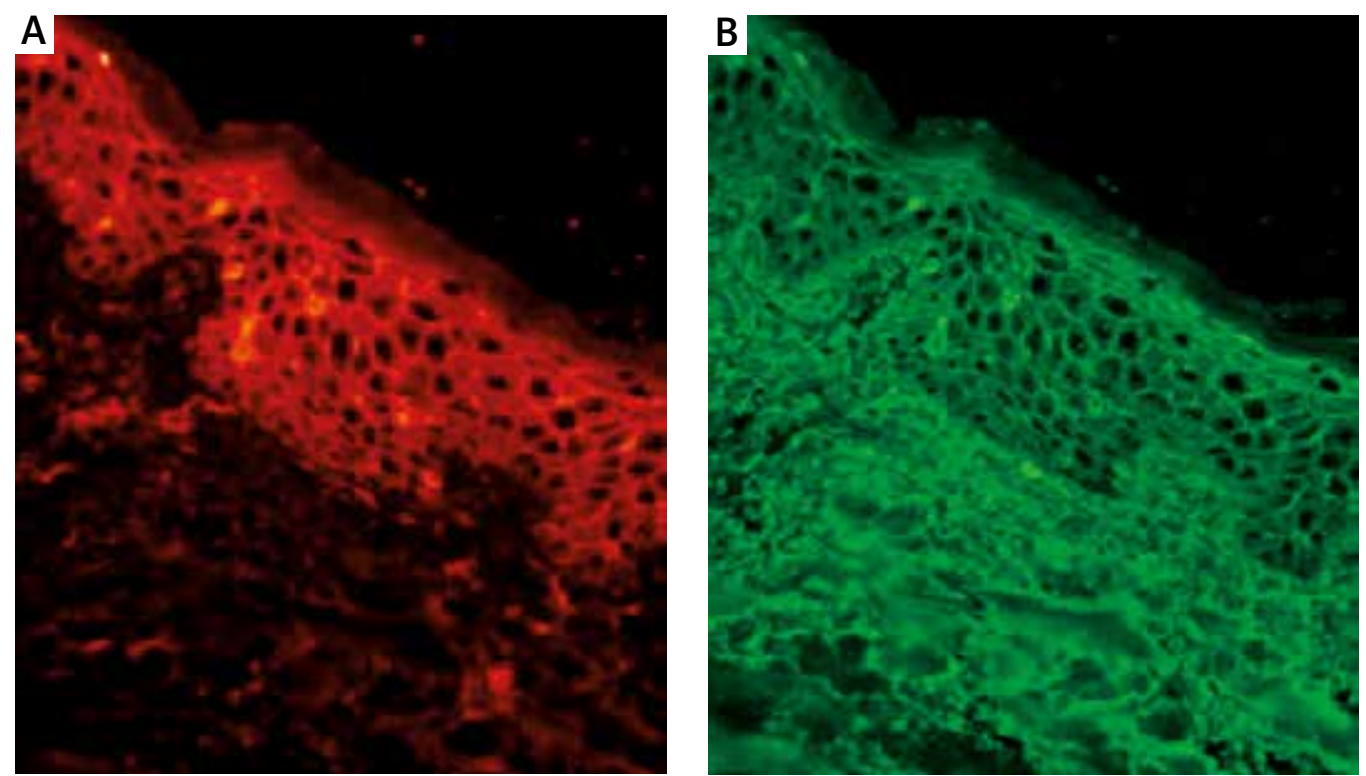

Figure 4. Langerhans cells: A - CD1a+ LC (TRITC), B - HLA-DR+ LC (FITC). Visible LC with small cell bodies and short, unbranched processes

In studies conducted on healthy volunteers, no difference in the number of LC was observed depending on the age. Authors noted a decrease of LC in the participants chronically exposed to UV radiation [26].

Studies conducted on cell cultures and animals showed that under the influence of UV radiation, the number and activity of LC decreased. It was also observed that LC migrate from the epidermis to the surrounding lymph nodes, whereas the number of dendritic cells in the dermis increases [27-30].

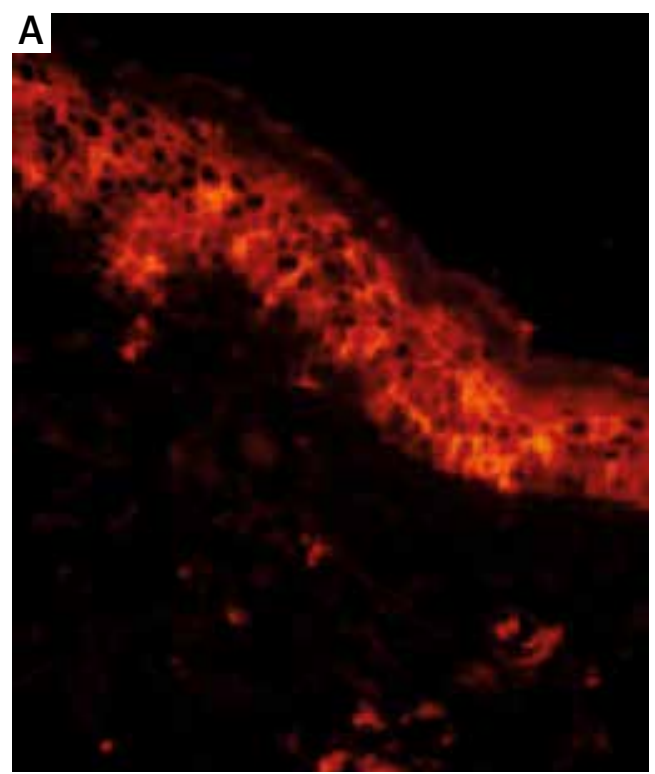

Figure 5. Langerhans cells: A - CD1a+ LC (TRITC), B - HLA-DR+ LC (FITC). Visible LC with large cell bodies and long,

branched dendritic processes

A very interesting research was conducted by Wong et al. They investigated the number of LC in skin samples collected from the deceased at the age of 20-78, from the anterior neck surface (exposed to UV radiation) and from the periumbilical area (not exposed to UV radiation). The authors did not observe a statistically significant difference in the number of $L C$ in the samples of skin exposed to UV compared to the skin protected from UV radiation. Similarly, no statistically significant difference between the number of LC in the skin exposed to UV ra-

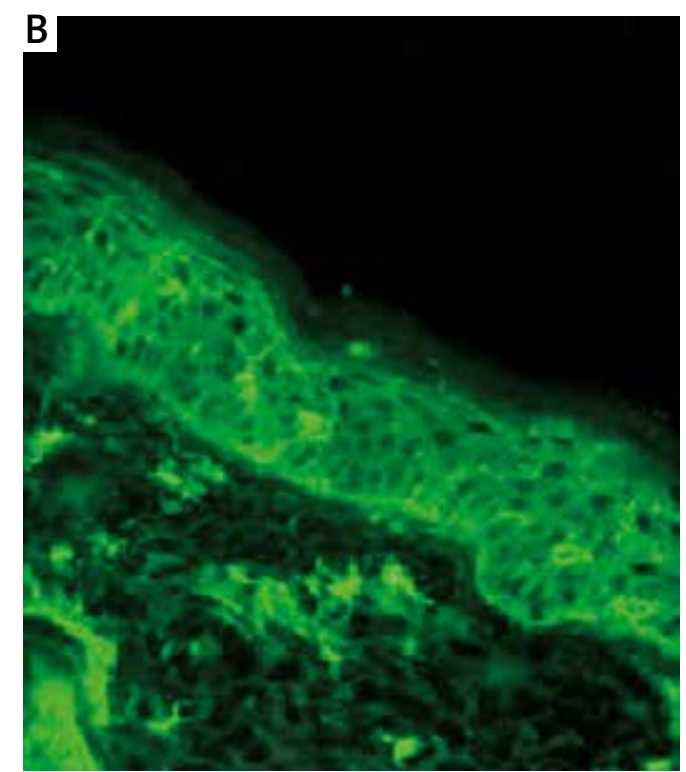




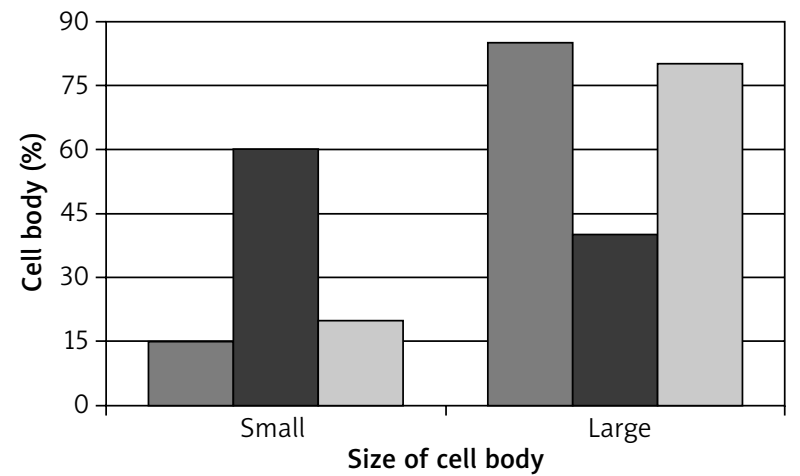

$\square$ Group I

-Group II

$\square$ Group III

Figure 6. A comparison of the size of a cell body between the studied groups

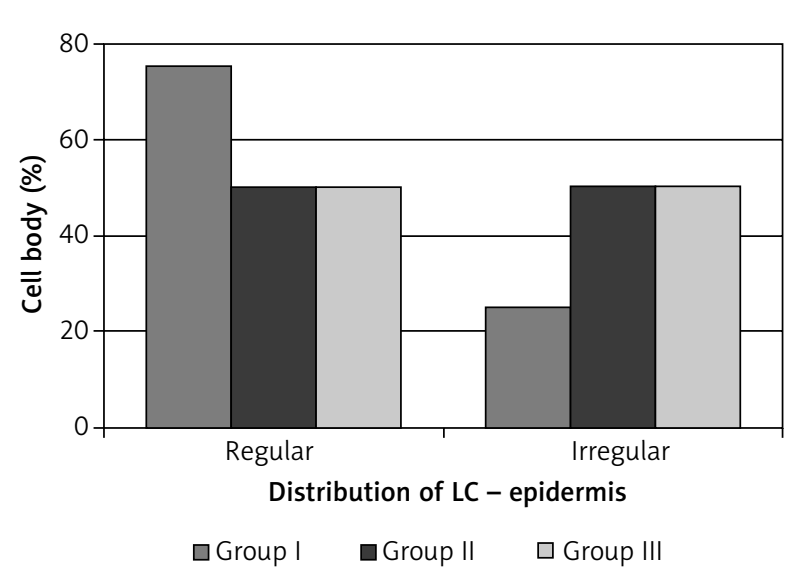

Figure 8. A comparison of the distribution of LC in the epidermis in individual groups

diation depending on the age was found. In the skin of women exposed to UV radiation, a lower number of LC was observed compared to men exposed to UV [31].

In studies investigating the influence of different doses of UVB on the number and morphological features of LC in the epidermis, it was demonstrated that UVB radiation induces two LC subtypes (differentiated based on the expression of HLA-DR) - with a low and high or normal expression of HLA-DR. It was proven that the population of LC with a low expression of HLA-DR was increasing depending on the applied UVB dose, whereas the population of $L C$ with a high expression of HLA-DR was decreasing. High UVB doses caused the decrease in the number of $L C$ including those with a high expression of HLA-DR. Authors concluded that the expression of HLA-DR on LC was probably a direct effect of UVB activity in low and average doses, which do not cause the cytostatic effect, or it could be the result of an indirect effect exerted by the cytokines released by the LC themselves or keratinocytes. A decrease in the number of $L C$ is a result of detrimental action of UVB [32, 33].

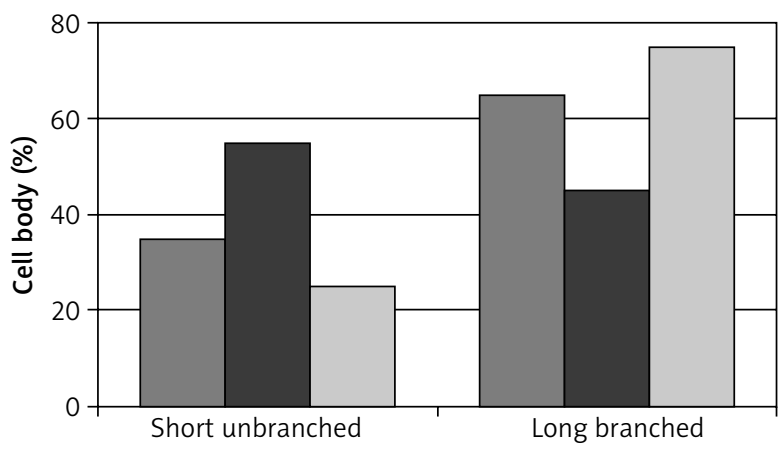

Shape of dendritic processes

$\square$ Group I

- Group II $\quad$ Group III

Figure 7. A comparison of the shape of dendritic processes in individual groups

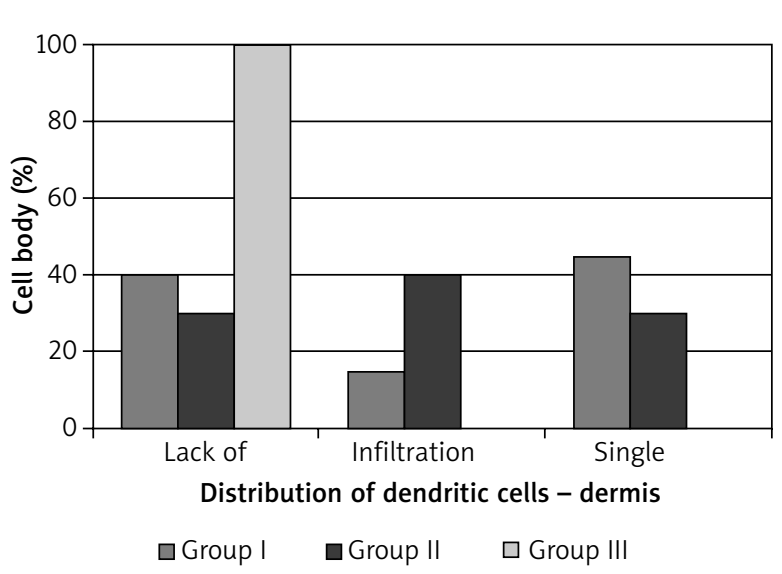

Figure 9. A comparison of the distribution of dendritic cells in the dermis in individual groups

Our own studies revealed changes in all the studied groups, but the most pronounced changes were observed in study group II which consisted of the women exposed to UV radiation. The results of our own studies are consistent with the data from available literature.

In our own studies, the number of CD1a and HLA-DR was evaluated in all participants. The correlation significance analysis conducted for the analysed parameters showed that the features of CD1a and HLA-DR have a significant correlation in all the groups. It is consistent with the assumptions of Murphy et al. and confirms the thesis that CD1a and HLA-DR are markers of Langerhans cells $[15,16]$. The largest number of CD1a+ LC was observed in group III and the smallest number - in group I. When comparing the number of CD1a LC between groups I and III, statistically significant differences were demonstrated at the significance level of $p=0.013$. The participants from group III used hormone replacement therapy (HRT) and were not exposed to excess UV radiation. Such elaborations do not appear in the available literature, so it is not possible to refer to them. On the basis of our 
own studies, it can be assumed that using HRT may have a certain influence on the normal functioning of LC.

The number of HLA-DR+ cells did not statistically differ between the groups. An increased expression of HLA-DR antigens in the epidermis in some of the studied participants is probably associated with the effective presentation of antigens to $T$ lymphocytes. The number of HLA$\mathrm{DR}^{+} \mathrm{LC}$ was lower than the number of CD1a+ $\mathrm{LC}$ in all the studied groups. In the studies of other authors, a greater expression of CD1a was also observed in various dermatoses [12, 32-36].

In our studies, a morphological evaluation was performed in all the women. When comparing the size of a cell body of LC it was observed that in the participants from the groups with endogenous ageing, both menopausal (group I) and chronological (group III), cells with large cell bodies and numerous branched and long dendritic processes were dominant. In the group with symptoms of photoageing (group II), mainly LC with small cell bodies and short, unbranched dendritic processes were observed. In some cases in group II, LC with very large nuclei and long dendritic processes - similar to those appearing in the acute phase of atopic dermatitis - were also observed [37, 38]. The presence of such type of cells can be explained by the occurrence of the inflammatory state which developed as a result of the influence of external factors (such as exposure to UV, smoking), so these cells differed from the others.

The distribution of LC in the epidermis was similar in all the studied groups, but it was statistically significantly different in the dermis. In group III, LC were not observed in the dermis. The infiltrations of LC in the dermis observed in some women from groups I and II can indicate the presence of the inflammatory state, local antigen presentation and lymphocyte activation. Based on the studies conducted by the authors, it was concluded that the influence of UV radiation on skin leads to the impairment of LC activity. Such changes are mainly caused by UVB radiation, which leads to the damage of $L C$ and keratinocytes. Even low doses of UVB, not inducing visible structural lesions in LC, induce the disturbances of antigen presenting mechanisms and a state of local immunosuppression [39-41].

In conclusion, it can be confirmed that the process of skin ageing depends on many different factors, which mutually overlap each other [41-43]. The results obtained from our own studies demonstrate quantitative and qualitative changes in LC during the skin ageing process, and require further research.

\section{Conclusions}

There are morphological and quantitative differences in LC, depending on the type of skin ageing. In the course of menopausal and chronological ageing, LC are characterised by long and multi-branched dendritic processes and large cell bodies. In the course of photoageing, the LC have short and poorly branched dendritic processes and small cell bodies.

\section{Conflict of interest}

The authors declare no conflict of interest.

\section{References}

1. Yaar M. Molecular mechanisms of skin aging. Adv Dermatol 1995; 10: 63-75.

2. Longo C, Casari A, Beretti F, et al. Skin aging: in vivo microscopic assessment of epidermal and dermal changes by means of confocal microscopy. J Am Acad Dermatol 2013; 68: 73-82.

3. Khavkin J, Ellis D. Aging skin: histology, physiology, and pathology. Facial Plast Surg Clin N Am 2011; 19: 229-34.

4. Zegarska B. The effects of the menopause on the skin. Eur Dermatol 2008; 3: 12-5.

5. Naylor EC, Watson RE, Sherratt MJ. Molecular aspects of skin ageing. Maturitas 2011; 69: 249-56.

6. Czarnecka-Operacz M, Jenerowicz D. Atopowe zapalenie skóry (cz. 1). Dylematy teoretyczne. Derm Dypl 2016; 4: 21-7.

7. Cumberbath M, Fielding I, Kimber I. Modulation of epidermal Langerhans cell frequency by tumor necrosis factoralpha. Immunology 1994; 81: 395-401.

8. Merard M, Manz MG, Karsunky H, et al. Langerhans cells renew in the skin throughout life under steady-state conditions. Nat Immunol 2002; 3: 1135-41.

9. Laube S. Skin infections and ageing. Ageing Res Rev 2004; 3: 69-89.

10. Mathers AR. Larregina AT. Professional antigen-presenting cells of the skin. Immunol Res 2006; 36: 127-36.

11. Bieber T. Die Langerhans-Zelle: Vorposten des Immunosystem in der Epidermis. Hautarzt 1986; 37: 424-31.

12. Felcyn E, Polasik K, Romanska-Gocka K, et al. Inflammatory dendritic epidermal cells in various forms of atopic dermatitis. Dermatol Klin 2013; 1: 5-9.

13. Błażewicz I, Biernat W, Kowalczyk A, et al. Adult onset of multisystem Langerhans cell histiocytosis with skin and lymph node involvement. Postep Dermatol Alergol 2015; 32: 225-8.

14. Nestle FO, Nickoloff BJ. Deepening our understanding of immune sentinels in the skin. J Clin Invest 2007; 17: 2382-5.

15. Angel CE, George E, Brooks AE, et al. Cutting edge: CD1a ${ }^{+}$ antigen-presenting cells in human dermis respond rapidly to CCR7 ligands. J Immunol 2006; 10: 5730-4.

16. Murphy GF, Bhan AK, Satos S, et al. A new marker for human Langerhan's cells. N Engl J Med 1981; 304: 385-96.

17. Ghersetich I, Troiano M, De Giorgi V, et al. Receptors in skin ageing and antiageing agents. Dermatol Clin 2007; 25: 655-62.

18. Mahbub S, Brubaker AL, Kovacs EJ. Aging of the innate immune system: an update. Curr Immunol Rev 2011; 7: 104-15.

19. Zouboulis CC, Makrantonaki E. Clinical aspects and molecular diagnostics of skin aging. Clin Dermatol 2011; 29: 3-14.

20. Yaar M, Gilchrest BA. Ageing and photoageing of keratinocytes and melanocytes. Clin Exp Dermatol 2001; 26: 583-91.

21. Ginaldi L, De Martinis M, Monti D, et al. The immune system in the elderly, activation-induced and damage-induced apoptosis. Immunol Res 2004; 30: 81-94. 
22. Gilchrest B, Murphy G, Soter N. Effect of chronologic aging and ultraviolet irradiation on Langerhans cells in human epidermis. J Invest Dermatol 1982; 79: 85-8.

23. Sunderkotter C, Kalden H, Luger TA. Aging and skin immune system. Arch Dermatol 1997; 10: 1256-62.

24. Grewe M. Chronological ageing and photoageing of dendritic cells. Clin Exp Dermatol 2001; 26: 608-12.

25. Lang PO, Mitchell WA, Lapenna A, et al. Immunological pathogenesis of main age-related diseases and frailty: role of immunosenescence. Eur Geriat Med 2010; 1: 112-21.

26. Czernielewski JM, Masouye I, Pisani A, et al. Effect of chronic sun exposed on human Langerhans cell densities. Photobiology 1988; 5: 116-20.

27. Thiers BH, Maize JC, Spicer SS, et al. The effect of aging and chronic sun exposure on human Langerhans cell populations. J Invest Dermatol 1984; 82: 223-6.

28. Bechetoille N, Dezutter-Dambuyant C, Damour O, et al. Effects of solar ultraviolet radiation on engineered human skin equivalent containing both Langerhans cells and dermal dendritic cells. Tissue Engineering 2007; 11: 2667-79.

29. Ishitsuka Y, Masunaga T, Koide C, et al. Repeat irradiation with suberythemal ultraviolet $B$ reduces the number of epidermal Langerhans cells. Arch Dermatol Res 2003; 295: 155-9.

30. Bennett M, Robinson MK, Baron ED, et al. Skin immune system and inflammation: protector of the skin or promotor of aging. J Investig Dermatol Symp Proc 2008; 13: 15-9.

31. Wong CP, Magnusson KR, Ho E. Aging is associated with altered dendritic cells subset distribution and impaired proinflammatory cytokine production. Exp Gerontol 2010; 45: 163-9.

32. Nakagawa S, Koomen CW, Bos JD, et al. Differential modulation of human epidermal Langerhans cell maturation by ultraviolet B radiation. J Immunol 1999; 163: 5192-200.

33. Omine $\mathrm{Y}$, Hinata $\mathrm{N}$, Yamamoto $\mathrm{M}$, et al. Regional differences in the density of Langerhans cells, CD8-positive T lymphocytes and CD68-positive macrophages: a preliminary study using elderly donated cadavers. Anat Cell Biol 2015; 48: 177-87.

34. Błaszczyk A, Karolewska-Szalbierz J, Jenerowicz D. Działanie promieniowania ultrafioletowego - aktualna wiedza w aspekcie dermatologicznym i alergologicznym. Alergol Pol 2015; 1: 21-7.

35. Rubel DM, Banetson R, Halliday GM. Bioactive tumor necrosis alpha but not granulocyte-macrophage colony-stimulating factor correlates inversely with Langerhans cell numbers in skin tumors. Int J Cancer 1998; 75: 210-6.

36. Komine M, Karakawa M, Takekoshi T, et al. Early inflammatory changes in the "perilesional skin" of psoriatic plaques: is there interaction between dendritic cells and keratinocytes? J Invest Dermatol 2007; 127: 1915-22.

37. McLoone P, Woods GM, Norval M. Decrease in Langerhans cells and increase in lymph node dendritic cells following chronic exposure of mice to suberythemal doses of solar simulated radiation. Photochem Photobiol 2005; 81: 1168-73.

38. Polasik K, Placek W, Romańska-Gocka K. Rola komórek Langerhansa w immunopatogenezie atopowego zapalenia skóry. Przegl Dermatol 2010; 97: 303-12.

39. Leitenberger J, Jacobe HT, Cruz PD. Photoimmunology-illuminating the immune system through photobiology. Semin Immunopathol 2007; 29: 65-70.

40. Bhushan M, Cumberbatch M, Dearman RJ, et al. Exogenous interleukin-1beta restores impaired Langerhans cell migration in aged skin. Br J Dermatol 2004; 150: 1217-8.
41. Shaw AC, Joshi S, Greenwood H, et al. Aging of the innate immune system. Curr Opin Immunol 2010; 22: 507-13.

42. Agrawal S, Gupta A. Impact of aging on dendritic cell functions in humans. Ageing Res Rev 2011; 10: 336-45.

43. Vukmanovic-Stejic M, Rustin M HA, Nikolich-Zugich J, et al. Immune responses in the skin in old age. Curr Opin Immunol 2011; 23: 525-31. 